International Joumal of Biological Sciences
2009; 5(2):201-204

(c) Ivyspring International Publisher. All rights reserved

Short Research Communication

\title{
Is sodium current present in human sinoatrial node cells?
}

\author{
Arie O. Verkerk ${ }^{\bowtie}$, Ronald Wilders, Marcel M.G.J. van Borren, and Hanno L. Tan \\ Heart Failure Research Center, Academic Medical Center, University of Amsterdam, Amsterdam, The Netherlands
}

Correspondence to: Dr. Arie O. Verkerk, Department of Physiology, Academic Medical Center, PO Box 22700, 1100 DE Amsterdam, The Netherlands. Phone: +31-20-5664644;Fax: +31-20-6976177; E-mail: A.O.Verkerk@amc.uva.nl

Received: 2008.11.13; Accepted: 2009.02.09; Published: 2009.02.13

\begin{abstract}
Pacemaker activity of the sinoatrial node has been studied extensively in various animal species, but is virtually unexplored in man. As such, it is unknown whether the fast sodium current $\left(\mathrm{l}_{\mathrm{Na}}\right)$ plays a role in the pacemaker activity of the human sinoatrial node. Recently, we had the unique opportunity to perform patch-clamp experiments on single pacemaker cells isolated from a human sinoatrial node. In 2 out of the 3 cells measured, we observed large inward currents with characteristics of $I_{\mathrm{Na}}$. Although we were unable to analyze the current in detail, our findings provide strong evidence that $I_{\mathrm{Na}}$ is present in human sinoatrial node pacemaker cells, and that this $I_{\mathrm{Na}}$ is functionally available at potentials negative to -60 $\mathrm{mV}$.
\end{abstract}

Key words: action potentials, humans, ion channels, sinoatrial node, sodium channels

The sinoatrial node (SAN) is the normal pacemaker of the mammalian heart and generates the electrical impulse for the regular, rhythmic contraction of the heart. Pacemaker activity of the SAN has been studied extensively in various animal species, but is virtually unexplored in man. Yet, it is unknown whether findings from animal studies can be directly extrapolated to man. According to the different heart rates, with high rates in small mammals and slower rates in large mammals, differences in pacemaker formation between animals and man can be expected $[1,2]$.

Therefore, we read with great interest the recent paper by Dobrzynski et al. [3]. In this nice and detailed review of the complex interaction of multiple ion currents in animal SAN pacemaker activity, the authors also provided an elaborate overview of the structure of human SAN. In addition, based upon clinical data from gene mutation carriers, they proposed that the hyperpolarization-activated current $\left(\mathrm{I}_{\mathrm{f}}\right)$ and fast sodium current $\left(\mathrm{I}_{\mathrm{Na}}\right)$ contribute to human SAN pacemaker activity. Yet, direct evidence that $I_{f}$ and $\mathrm{I}_{\mathrm{Na}}$ are present in the human SAN was lacking. Therefore, we were particularly pleased by their inclusion of new data on expression of ion channel proteins in human SAN, as revealed by immunohistochemistry. These data show that HCN4 channel proteins (responsible for $\mathrm{I}_{\mathrm{f}}$ ) are present in human SAN, and that Nav1.5 channel proteins (responsible for $\mathrm{I}_{\mathrm{Na}}$ ) are present in atrial muscle and in the periphery, but not the center, of human SAN.

Recently, we had the unique opportunity to perform a patch-clamp study on isolated human SAN cells [4]. In a patient who underwent SAN excision because of inappropriate sinus tachycardias originating from the SAN region (see [4] for clinical details), the SAN region was identified as the site of earliest activation using epicardial activation mapping and subsequently a wide resection of this region was performed. From this excised tissue, we enzymatically isolated cells, and recorded action potentials and membrane currents using the whole-cell patch-clamp technique at $36 \pm 0.2^{\circ} \mathrm{C}$ (for recording conditions, see [4]). In our study the number of successfully meas- 
ured cells was limited, importantly due to the low living-cell yield $(<5 \%)$. Nevertheless, we found that SAN pacemaker cells $(n=3)$ had spontaneous action potentials with a cycle length of $828 \pm 15 \mathrm{~ms}$ (mean \pm SEM), slow diastolic depolarization $(48.9 \pm 18$ $\mathrm{mV} / \mathrm{s}$ over the first $100 \mathrm{~ms}$ ), and a maximal diastolic potential (MDP) of $-61.7 \pm 4.3 \mathrm{mV}$ [4]. Figure 1A shows typical action potentials recorded from one of the cells. In addition, 2-s hyperpolarizing voltage-clamp steps from a holding potential of $-40 \mathrm{mV}$ (see Fig. 1B for protocol) revealed that these cells had a
$\mathrm{Cs}^{+}$-sensitive, time-dependent, inward current that activated upon hyperpolarizing voltage steps from $-40 \mathrm{mV}$ [4]. These properties are characteristic for $\mathrm{I}_{\mathrm{f}}$ and thus provide evidence that the presence of $\mathrm{HCN} 4$ protein in the human SAN, as revealed by immunohistochemistry in the study by Dobrzynski et al. [3], results in a functional $\mathrm{I}_{\mathrm{f}}$, although we cannot rule out that other $\mathrm{HCN}$ transcripts (HCN1, HCN2) are also involved. In our previous studies, we also provided evidence that $\mathrm{I}_{\mathrm{f}}$ substantially contributes to the intrinsic pacemaker activity of human SAN cells $[4,5]$.

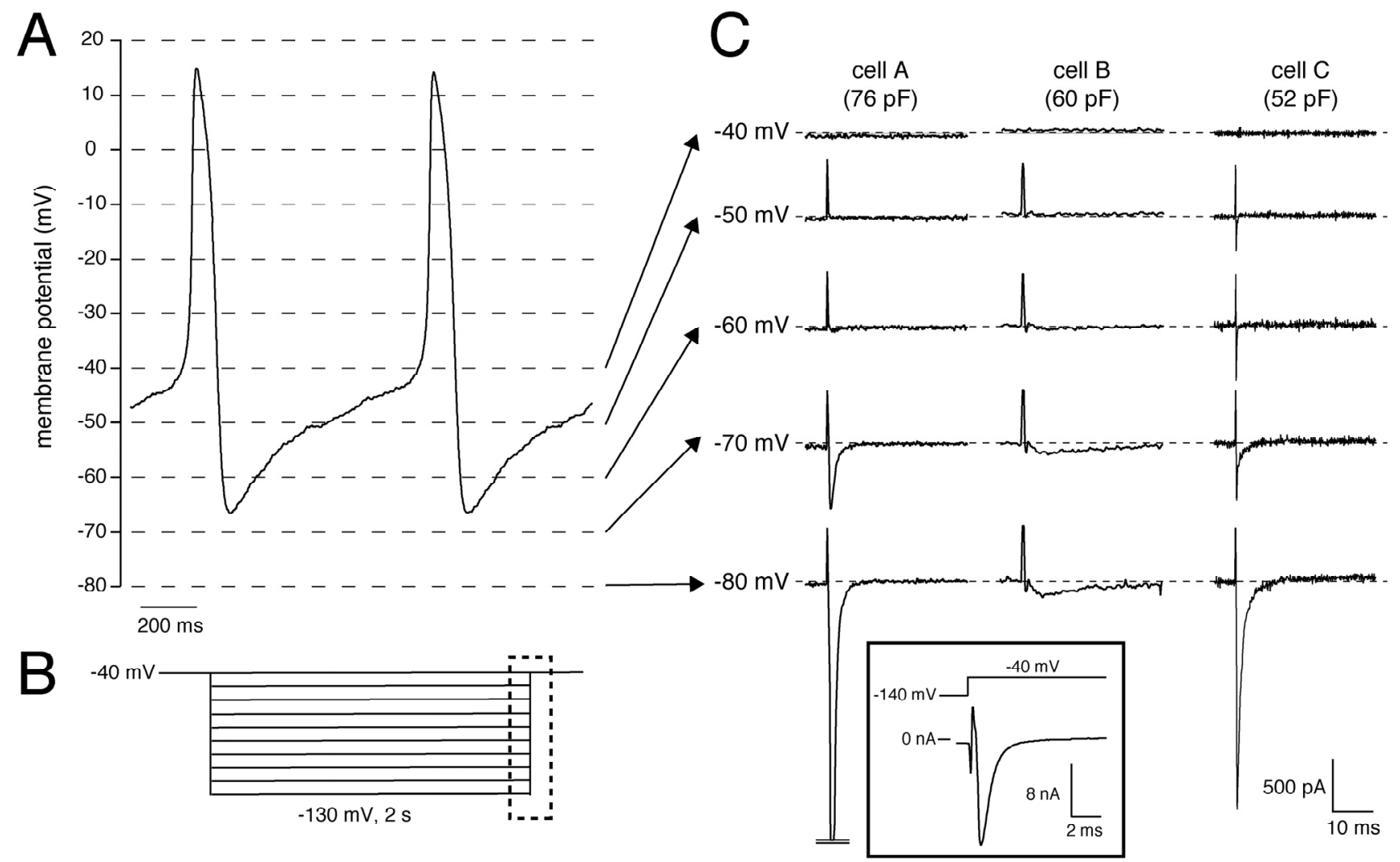

Figure I. (A) Typical action potentials of a human SAN cell. (B) Voltage-clamp protocol used. (C) Current recording of all measured cells showing activation and inactivation of the $\mathrm{Na}^{+}$current in response to the depolarizing step from the test potential, ranging from -80 to $-40 \mathrm{mV}$, to the holding potential of $-40 \mathrm{mV}$. Dashed lines indicate zero current level. Current recorded at $36 \pm 0.2^{\circ} \mathrm{C}$ in the whole-cell configuration of the patch-clamp technique in the presence of $2 \mathrm{mM} \mathrm{Cs}^{+}$to block $\mathrm{I}_{\text {f }}$. Sodium concentration was 140 and $5 \mathrm{mM}$ in the bath and pipette solution, respectively. Inset, Current recording from Cell A with adapted amplifier settings. Note the $>10 \mathrm{nA}$ current amplitude.

Interestingly, but not previously discussed, we also observed large inward currents that rapidly activated and inactivated upon switching off the hyperpolarizing pulses of $-60 \mathrm{mV}$ and more negative in 2 out of the 3 cells measured. Figure $1 \mathrm{C}$ shows the currents recorded from all three cells measured. The presence of the large transient currents in Cells A and $\mathrm{C}$ are of particular interest. Given their amplitude and time course, these transient inward currents are most likely $\mathrm{I}_{\mathrm{Na}}$, which activates by the depolarizing voltage step at the end of the protocol (dashed box in Fig. 1B), since $\mathrm{Na}^{+}$channel inactivation is partially removed by the preceding hyperpolarization. The large inward currents typically saturated using our default amplifier settings for recording from SAN cells. In Cell A, we were able to perform a measurement with adapted amplifier settings (Figure 1C, inset), and found that the amplitude exceeded $10 \mathrm{nA}$. Unfortunately, be- 
cause the voltage-clamp control at the employed physiological temperature and $\left[\mathrm{Na}^{+}\right]$gradient was insufficient, we were unable to characterize the $\mathrm{I}_{\mathrm{Na}}$ kinetics in detail. Nevertheless, our findings provide strong evidence that $\mathrm{I}_{\mathrm{Na}}$ is present in human SAN cells, in accordance with the recent finding by Dobrzynski et al. [3] that $\mathrm{Na}_{\mathrm{v}} 1.5$ proteins are present in the periphery of the human SAN, and that this $\mathrm{I}_{\mathrm{Na}}$ is functionally available at potentials negative to -60 $\mathrm{mV}$.

The importance of $\mathrm{I}_{\mathrm{Na}}$ in SAN pacemaking has traditionally been debated, because $\mathrm{I}_{\mathrm{Na}}$ is assumed to be small or absent in SAN cells (see [6] and primary references cited therein). In addition, because of the moderately negative MDP and long diastolic depolarization phase of single SAN cells (Fig. 1A), most $\mathrm{Na}^{+}$channels may reside in the inactivated state and are not available for activation. However, we think that $\mathrm{I}_{\mathrm{Na}}$ may contribute to human SAN pacemaker activity for the following reasons: (1) Nav1.5 proteins are present in the periphery of the human SAN [3], (2) a large inward current with $\mathrm{I}_{\mathrm{Na}}$ characteristics is present in human SAN cells (Fig. 1), and (3) under in vivo conditions, the atrium exerts an effective hyperpolarizing load on the periphery of the SAN (see [7] and primary references cited therein), thereby bringing the peripheral cells to a more hyperpolarized potential where not all $\mathrm{Na}^{+}$channels are inactivated.

Our experiments were performed on a limited number of SAN pacemaker cells isolated from just one patient with inappropriate tachycardias originating from the SAN region. As such, there may have been abnormalities in the electrophysiology of the SAN pacemaker cells. Although the sudden onset and termination suggested that the tachycardias were based on reentrant excitation [4], it cannot be excluded that these tachycardias have had impact on our findings. In dog atrial myocytes, chronic atrial tachycardia (400 $\mathrm{bpm}$ ) resulted in decreased $\mathrm{I}_{\mathrm{Na}}$ density, however, without changes in gating properties [8]. In addition, due to the limited number of SAN cells and limited lifespan when patch-clamped (leak currents, hypercontracture, and cell death), we were not able to characterize the properties of the recorded current in detail. We observed inward currents that rapidly activated and inactivated in response to the depolarizing voltage clamp steps to $-40 \mathrm{mV}$, which are not only characteristic properties of $\mathrm{I}_{\mathrm{Na}}$, but also of the T-type $\mathrm{Ca}^{2+}$ current $\left(\mathrm{I}_{\mathrm{Ca}, \mathrm{T}}\right)$. Nevertheless, we think that the observed currents are $\mathrm{I}_{\mathrm{Na}}$ rather than $\mathrm{I}_{\mathrm{C} a, \mathrm{~T}}$ for several reasons. First, the amplitude of the recorded currents was large, while the $\mathrm{I}_{\mathrm{Ca}, \mathrm{T}}$ density in SAN cells becomes smaller as body mass increases (mouse>guinea pig>rabbit>pig) [9]. In porcine $S A N$ cells, $\mathrm{I}_{\mathrm{Ca}, \mathrm{T}}$ was even negligibly small [9]. Second, $\mathrm{I}_{\mathrm{Ca}, \mathrm{T}}$ has never been recorded in human cardiomyocytes [9].

Various TTX-sensitive "brain-type" $\mathrm{I}_{\mathrm{Na}}$ channel isoforms have been detected in mice, rat, and rabbit SAN, i.e., $\mathrm{Na}_{v} 1.1, \mathrm{Na}_{v} 1.3$, and $\mathrm{Na}_{v} 1.6$ (see $[2,10]$ and primary references cited therein). In our study, we did not attempt molecular characterization of human SAN pacemaker cells or TTX-sensitivity measurements. However, the $\mathrm{I}_{\mathrm{Na}}$ inactivation was complete at $-60 \mathrm{mV}$, suggesting that the current is carried by $\mathrm{Na}_{\mathrm{V}} 1.5$ rather than "brain-type" $\mathrm{I}_{\mathrm{Na}}$ channel isoforms, which inactivate at less negative potentials [2]. Further research is required to determine the nature of $\mathrm{Na}^{+}$channels in human SAN in detail. Despite the above limitations, we think that our first demonstration of the functional presence of $\mathrm{I}_{\mathrm{Na}}$ in human SAN cells significantly adds to our knowledge of pacemaker formation in man.

\section{Acknowledgment}

Dr Tan was supported by the Royal Netherlands Academy of Arts and Sciences and the Netherlands Organization for Scientific Research (ZonMW-Vici grant 918.86.616).

\section{Conflict of Interest}

The authors have declared that no conflict of interest exists.

\section{References}

[1] Opthof T. The normal range and determinants of the intrinsic heart rate in man. Cardiovasc Res. 2000; 45: 177-84.

[2] Mangoni ME, Nargeot J. Genesis and regulation of the heart automaticity. Physiol Rev. 2008; 88: 919-82.

[3] Dobrzynski H, Boyett MR, Anderson RH. New insights into pacemaker activity: promoting understanding of sick sinus syndrome. Circulation. 2007; 115: 1921-32.

[4] Verkerk AO, Wilders R, van Borren MMGJ, Peters RJG, Broekhuis E, Lam K, Coronel R, de Bakker JMT, Tan HL. Pacemaker current $\left(\mathrm{I}_{\mathrm{f}}\right)$ in the human sinoatrial node. Eur Heart J. 2007; 28: 2472-8.

[5] Verkerk AO, van Borren MMGJ, Peters RJG, Broekhuis E, Lam KY, Coronel R, de Bakker JM, Tan HL, Wilders R. Single cells isolated from human sinoatrial node: action potentials and numerical reconstruction of pacemaker current. Conf Proc IEEE Eng Med Biol Soc. 2007; 2007: 904-7.

[6] Veldkamp MW, Wilders R, Baartscheer A, Zegers JG, Bezzina $\mathrm{CR}$, Wilde AAM. Contribution of sodium channel mutations to bradycardia and sinus node dysfunction in LQT3 families. Circ Res. 2003; 92: 976-83.

[7] Verheijck EE, Wilders R, Bouman LN. Atrio-sinus interaction demonstrated by blockade of the rapid delayed rectifier current. Circulation. 2002; 105: 880-5.

[8] Gaspo R, Bosch RF, Bou-Abboud E, Nattel S. Tachycardia-induced changes in $\mathrm{Na}^{+}$current in a chronic dog model of atrial fibrillation. Circ Res. 1997; 81: 1045-52.

[9] Ono K, Iijima T. Pathophysiological significance of T-type $\mathrm{Ca}^{2+}$ channels: properties and functional roles of T-type $\mathrm{Ca}^{2+}$ channels in cardiac pacemaking. J Pharmacol Sci. 2005; 99: 197-204. 
[10]Du Y, Huang X, Wang T, Han K, Zhang J, Xi Y, Wu G, Ma A. Downregulation of neuronal sodium channel subunits Nav1.1 and Nav1.6 in the sinoatrial node from volume-overloaded heart failure rat. Pflügers Arch. 2007; 454: 451-9. 